\title{
Science Academies' 3rd Refresher Course On Advances in Molecular Biology
}

\author{
Sponsored by \\ Indian Academy of Sciences, Bengaluru \\ Indian National Science Academy, New Delhi \\ The National Academy of Sciences, India, Allahabad \\ in collaboration with \\ Department of Microbiology and Cell Biology \\ Indian Institute of Science \\ Bangaluru 560012 \\ 28 January to 10 February 2019
}

Applications are invited from faculty (preferably less than 45 years of age) teaching undergraduate and/or postgraduate courses in colleges/universities. The number of seats available is 10 for local and 20 for outstation participants. The applicants have to enclose $\mathrm{CV}$ with a brief statement on why he/she is interested in this course. The application has to be duly forwarded by the Head of the Department/Chairman/Principal with a commitment that the candidate if selected, will be provided leave/OOD for the duration of the course. The selected candidates will be provided with roundtrip bus/train (IIIAC) fare by the shortest route and local hospitality during the course. Applications should be submitted ONLINE by clicking the following link:

http://web-japps.ias.ac.in: 8080/Refreshcourse/ADV.jsp

DIRECTOR: Prof. Umesh Varshney, Head, Division of Biological Sciences, Department of Microbiology and Cell Biology, Indian Institute of Science, Bengaluru.

COORDINATORS: (1) Prof. Saumitra Das, Department of Microbiology and Cell Biology, Indian Institute of Science, Bengaluru. (2) Prof. P Kondaiah, Department of Molecular Reproduction, Development and Genetics, Indian Institute of Science, Bengaluru. (3) Prof. H A Ranganath, Visiting Professor, Division of Biological Sciences, Indian Institute of Science, Bengaluru.

\section{THEME: ADVANCES IN MOLECULAR BIOLOGY}

(A) LECTURES: Nucleic acid and chromatin structure; Nucleic acid transactions - Replication, Transcription and Translation regulation; Ribosome biogenesis; Protein structure and function; Molecular immunology; Genetic Recombination and DNA Repair; Biology of RNA - splicing, editing, microRNAs, Ribozyme; molecular oncology; Genes in development and differentiation; Epigenetics and gene regulation; Molecular biology of viruses; Restriction enzymes and modifications; Genetic engineering; Neurobiology; Bioinformatics- structural, functional and comparative genomics; Metagenomics; Genome editing; Big-data biology; Synthetic genomes; Evolution of genomes; Molecular basis of evolution \& its associated theories. (B) PRACTICALS: 1) Nucleic acid isolation, detection and quantification: 2) Site directed mutagenesis (inverse PCR method) 3) Protein expression and purification 4) Reporter gene activity (ß- galactosidase activity or luciferase activity) 5) Animal cell culture PROPOSED RESOURCE PERSONS: Faculty members from the Indian Institute of Science and other institutions in Bengaluru.

Contact address: Coordinator, Science Education Programme, Indian Academy of Sciences, C.V. Raman Avenue, Sadashivanagar, Bengaluru 560080 (Email: sep@ias . ac. in).

Last date for receipt of application: 15 December 2018 